\title{
魚群の輪紋学的考察一予報 \\ 東北海区の漁獲サンマについて
}

\author{
安田秀明 \\ (1960年11月 7 日受理)
}

\section{GRANOGRAPHY FOR FISH-A PRELIMINARY REPORT. SAURY PIKE STOCKS IN TOHOKU (NORTH-EASTERN) SEA REGION OF JAPAN IN THE ASPECT OF SCALE-RING FORMATION}

\author{
Hideaki YASUDA*
}

\begin{abstract}
Examining the graphic representations of body-length distribution by KIMURA ${ }^{37}$ for catches of saury pike, it was noticed a peculiar situation that in fishing seasons extending every year from September to December, during which the fish continues to increase in body-length, the values for the most predominant body-length characteristic of every mode of body-length distribution changes in some cases suddenly from a route to another and in other cases stepwise from a higher level to a lower (see Fig. 1).

In the light of the relationship found between body-length and time of scale-ring formation or granographically assessed age of saury pike, which is now in preparation to be published, the abovementioned peculiar phenomena about body-length distribution were interpreted as a reflection of that any school of saury pike is possible to be replaced by or mingled with that of another age. As to the fishing ground where such replacing or mixing is realized, its yearly change in geographic position seems to be negligible. It may be regarded, therefore, that a school of saury pike temporarily form separate schools on the way of their migration toward the north and the south along the coast of Japan proper.
\end{abstract}

サンマは体長の広範用にるたる周年の試料が得られないので，㴔獲魚の体長組成に関する山の位置に相当 する体長值の季節的変化からは成長曲線を決定することが困難である。

著者はサンマの円鱗に現われる輪紋注 1 年に 2 回，2月と9月とに形成されることを知つた。

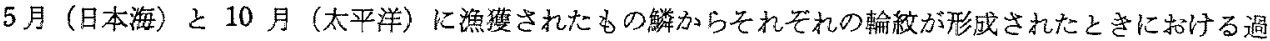
去の体長を求め，之の計算体長と輪紋が形成された月との間の関倸から成長曲線を求めだ。

漁獲魚の成長の季節的渦程を示寸図の上に計算体長の結果を重衫て書くと10 月の試料によるものは体長

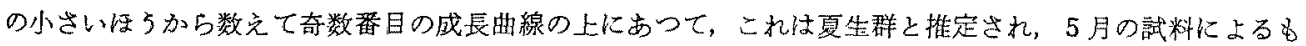
のは偶数番目の曲線の上にあつて, これは冬生群と擭定されだ2。

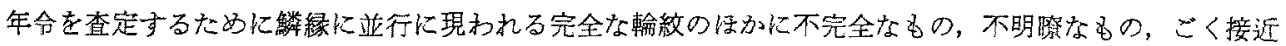

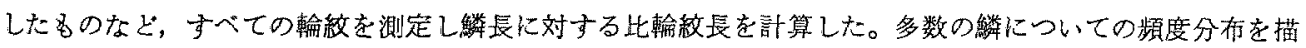
いた曲線の型は夏生群と冬生群とで著しい違いが認められた。この種の曲線は種族系統の違いを判定する1 つの決め手々なるもので，魚群の生活履歷曲線々名付けることが適当である々考充られる。

本文に和いては輪紋の特徴を研究した上述の結果を適用することによつて, 盛漁期のサンマ群の体長組成 の等の移り変わりを2つの種族系統群の相互混合，すなわち漁期と漁場の移動化伴なら混合と，別の年令魚 その交代として説明し，魚群の住み分けについて若干の知見を得たので報告する。

*真京水産大学 (Tokyo Univ. Fish., Shiba Kaigandori 6, Minato-ku, Tokyo), 
木村 ${ }^{3)}$ は棒受網で漁獲され塩鉒港に陸揚された昭和 $24 \sim 32$ 年のサンマについて，9１2 月の旬別体長組 成の変化を調べ，体長 $25 \sim 29 \mathrm{~cm}$ に出現頻度の岀をるつ中型魚と $29 \sim 32 \mathrm{~cm}$ に滦をもつ大型魚とに分けて 体長組成の峯が漁期に応じて增・减する現象を舆群の漁場に持ける添加・離脱として資源学的に説明した。

木村氏の諭文第 $15 \sim 17 \cdot 20 \cdot 22 \sim 25$ および 29 図から漁獾サンマの旬别体長組成に関する䇣の位犆を読 みとつて, 漁期の推移とともに体長が増大の傾向にある昭和 $24 \cdot 27$ 年 (A 型群) の大型魚と, 昭和 $24 \cdot 25$ 年 ( $\mathrm{D}$ 型) の中型魚, 体長が減少の傾向にある昭和 $29 \cdot 30 \cdot 32$ 年（B型）の大型魚と，大型魚が多量には 共存しなかつた昭和 $26 \cdot 28 \cdot 31$ 年 (C型)，大型魚と共存した昭和 $27 \cdot 29 \cdot 30 \cdot 32$ 年 (C型)の中型魚と

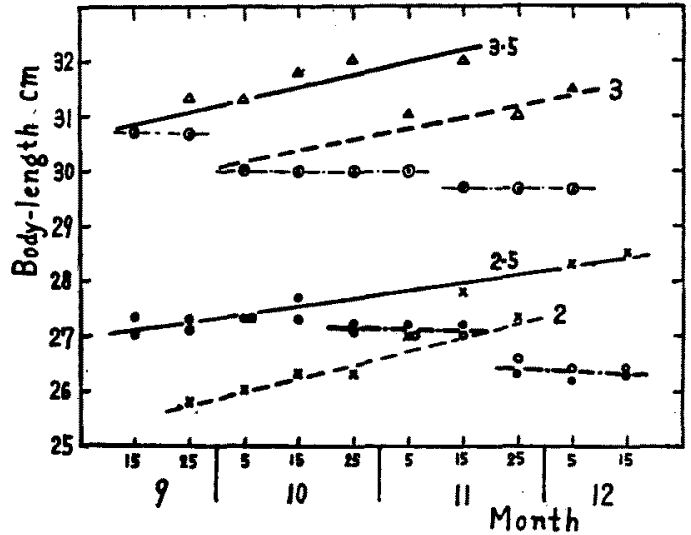

Fig. 1. Seasonal variations of the most predominant body-length observed for saury pike caught in Tohoku Sea Region. The numerals in the figure stand for assessed ages, 3.5 and 2.5 being assigned to the fish hatched in summer and 3 and 2 to those hatched in winter.
$\triangle: 1949,152$ (group A),
$0: ' 52, ' 54, ' 55,{ }^{\prime} 57$ (C), $x: 149, ' 50$ (D).
๑: '54, '55, 157 (B)
: '51, '53, '56 (C) をたがいに分けて，それぞれの体長の月別， 旬別の平均值を求め，これを図示して Fig. 1 を得た。これに著者がさきに得たサンマの成 長曲線から終漁期頃の年令を数它たるのを Fig. 1 の右のほ 5 へ畫き込九だ。3.5 年魚と 2.5 年魚とあるのは夏生群で， 3 年魚と 2 年 魚は冬生群である。

A 型群は 3.5 年魚と 3 年魚とが，D型群は 2 年魚と 2.5 年魚とがいずれ䡎漁期の後半で 交代したるのと若充られるが， B型群ではは じめ 3.5 年魚だけであつたすのが， 3 年㯖と 混合し，つついて3年魚だけとなり，さらに 3 年焦と 2.5 年魚と加 10 月中旬と 11 月中 旬との 2 回にわたつて混合していると胃られ る。C型群では初漁期の 2.5 年魚が 10 月下 句に 2 年魚亡混合し, 11 月中旬には 2 年魚た けとなりつづいて 1.5 年魚と混合したすの と考光られる。

昭和 24 年の漁獲魚の体長群は $(A \cdot D)$, 27 年仕 $(\mathrm{A} \cdot \mathrm{C}), 29 \cdot 30 \cdot 32$ 年江 $(\mathrm{B} \cdot \mathrm{C})$ の組合わせであるが，25 年は（D），26・28・31 年は（C）だけであつた。同じ年に（B・D）の組合わせ が起らないのは，主群の 2.5 年魚が共通していることによるるのと思われる。

Fig. 1 から炊のことが知られる。

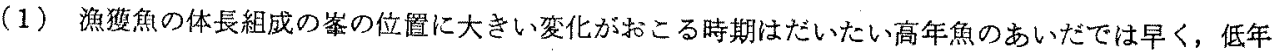
魚のあいだでは幄い。

（2）大型舆と中型焦とでは違つた時期に混合なり交代なりが起つている。

（3）中型魚に混合・交代のおこる時期は，大型魚の有無に関傒しない。これらの関係は年度別に見ても まつたく同様であつた。

な特，（4）初漁期の体長組成からその年の瀂萑魚の体長組成の型を予知することができるはずである。

体長組成の型が A・D のような交代型になる場合と， B・Cのような混合型になる場合とに相当する漁場 の位置の違いを調べるために，同じ木村氏の諭文から9月中〜下旬の漁場図を写しとつて，体長組成の型 $\mathrm{A} \cdot \mathrm{B} \cdot \mathrm{C}$ およ゙ D の年度別に，それでれ1つの閉じた曲線で国んでみると Fig. 2 のようになる。すなお ち, 大型魚, 中型䁩いずれも初漁期に道東区特に $41^{\circ}$ 以北, $145^{\circ}$ 以東に張り出した漁場からはじまつて, 南下する場合にはいずれの年にも大型與では A 型，中型魚では D 型となつて，とるに交代型になつている ことが知られた。

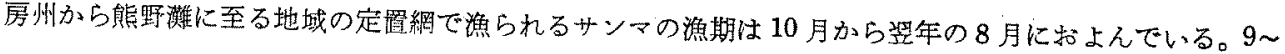




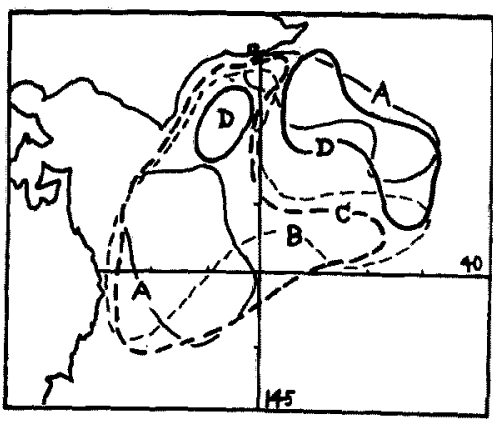

Fig. 2. Yearly invariable geographic positions of fishing grounds for saury pike of different stocks in an early fishing season $(1947 \sim 1957)$. Capital letters in the figure stand for different fish stocks.

12 月に東北の漁場で漁られるサンマ群は主として前 記の地域から北上したものと考えられるが，魚群につ いての泥合・交代の执こる時期が主として年令によつ て違らこと，同じ年令群でも初漁期の漁場の位置に関 俰してその年の体非組成の型が違らことから，魚群の 北上の限界が年令と海況によつて同じではないるのと 考完られる。

この点を確かめるために, 体長組成に急な变化の起

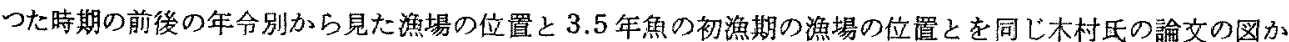
ら军しとつてそれそれの年度について整理的に集め、そのいずれの年にる共通な漁場だけを選んで曲線で囲 んでみた (Fig. 3)。

魚群の混合・交代の始变万漁埸の位置は夏生群・冬生群ともに高年與のものは北部にあり，低年魚のもの は南部にある。漁期と漁填の移動に伴なつて回遊がそれぞれの魚群の伤留した位置から始まり，または䅂つ ている場合のあること考克ると (Fig. 1 参照)，系統と年令とによつてだいたいの住み分けが行なかれる

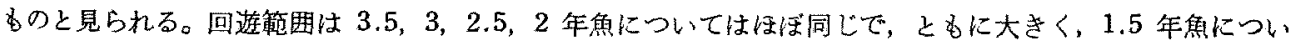
ては極めて小さいといえる。

\section{文献}

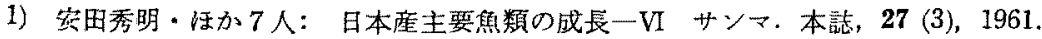

2) 一：鱗の翰紋の研究一IV 種族の系较判別入の利用, 未印刷.

3) 木村喜之助：東北海区サンマ漁沉に対する資源学的考察. 東北海区水産研究所研究報告 14, 1960.

4) K. Kimura: A population study on autumn Pacific Saury (cololabis saira) in the NorthEastern sea of Honshu, Japan. Tohoku Regional Fisheries Research Laboratory, No. 14, 1960 . 